\title{
Scion Substitution: A New Strategy to Control Citrus Variegated Chlorosis Disease
}

\author{
Silvio A. Lopes ${ }^{\dagger}$ \\ Department of Research and Development, Fundecitrus, Araraquara 14807-040, São Paulo, Brazil
}

\begin{abstract}
Citrus variegated chlorosis (CVC) disease, caused by the xylem-limited and insect-transmitted bacterium Xylella fastidiosa, has caused severe losses in orange production in Brazil. Disease control requires insecticide applications, tree removal, and pruning of symptomatic branches. Pruning success has been erratic, especially in areas of high disease incidence. In this work, in planta X. fastidiosa distribution and the effectiveness of severe pruning procedures for curing diseased adult trees were investigated. Most sampled upper parts of the trees contained X. fastidiosa, but at higher frequencies in symptomatic branches. Removal of all main

of healthy scions but killed 10 to $30 \%$ of the remaining trunks. Removal of all scion and grafting the newly sprouted shoots of 'Rangpur' lime (Citrus limonia Osbeck) or 'Cleopatra' (Citrus reshni Hort. ex Tan.) rootstocks with healthy buds allowed production of fast-growing and productive new scions that remained free from CVC for at least 2 years in four locations. With this method, highly affected trees do not need to be fully removed and the costs involved in this practice and in young tree acquisition and plantings are circumvented; therefore, it is a feasible option for less technically inclined small growers in Brazil.
\end{abstract} branches (decapitation) was not effective and revealed a 20 to $30 \%$ incidence of latent infections. Trunk decapitation resulted in a higher number
Keywords: Xylella fastidiosa, CVC, pruning, tree decapitation
The Gram-negative bacterium $X$. fastidiosa causes systemic diseases that affect several commercial hosts around the world, sometimes leading to devastating economic losses. The bacterium is limited to the xylem and is transmitted by several species of leafhoppers. Initial reports of the impact of $X$. fastidiosa infections in grapevines in California were made in 1942, when the causal agent was believed to be a virus (Davis et al. 1978; Hewitt et al. 1942). Later, $X$. fastidiosa was found to affect many other important hosts, including peach and oleander in the United States (Purcell et al. 1999; Wells et al. 1981b), citrus and coffee in South America (de Lima et al. 1998; Paradela Filho et al. 1997; Rossetti et al. 1990), and olive trees in Italy (Saponari et al. 2013).

Regarding citrus, $X$. fastidiosa was first observed in sweet oranges in 1984 in Argentina (Contreras, 1992), and then in 1987 in Sao Paulo State (SPS), Brazil (Rossetti et al. 1990), causing what was called citrus variegated chlorosis (CVC) or 'amarelinho' disease, which referred to the yellow, gummy spots on leaves or the small, hard, early ripened yellow fruit (Lee et al. 1993; Rosseti and De Negri 1990). The pathogen was later demonstrated to be transmitted by 12 species of leafhoppers (Gravena et al. 1998; Lopes 1996; Redak et al. 2004). The wide distribution and high prevalence of the vectors favored $X$. fastidiosa dissemination, which caused disease in $25 \%$ of field trees in 1996 and reached $44 \%$ in 2003, when losses of more than $\$ 100$ million US per year in fruit production were estimated (Lopes et al. 2004). After 2012, the incidence of CVC in SPS and Minas Gerais State decreased to $1.3 \%$ of the 194.4 million orange trees in 2018 (Fundecitrus 2018a, b), probably as a collateral consequence of the intensification of insecticide sprays and removal of large areas of abandoned and unproductive groves performed in attempts to control Huanglongbing (HLB), an even more destructive insect-transmitted bacterial disease. However, CVC continues to impact fruit production on small farms, especially those located in other states of Brazil and in other neighboring South American countries.

${ }^{\dagger}$ Corresponding author: S. Lopes; silvio.lopes@ fundecitrus.com.br

*The $\boldsymbol{e}$-Xtra logo stands for "electronic extra" and indicates that two supplementary figures and one supplementary table are published online.

The author(s) declare no conflict of interest.

Accepted for publication 11 July 2019.

(C) 2020 The American Phytopathological Society
CVC is a disease of sweet oranges (Citrus sinensis). Despite the wide distribution of the insect vectors, during the past 30 years of living with $\mathrm{CVC}$, no citrus other than sweet orange has been affected by the disease. The susceptibility of oranges and the resistance of limes and mandarins were confirmed by pinprick inoculation experiments using in vitro cultures of the pathogen. X. fastidiosa infected 59 to $75 \%$ and induced symptoms in 54 to $63 \%$ of the inoculated orange plants, on which 11 to $26 \%$ of xylem vessels in leaf petiole appeared to be occluded (Garcia 2006; Garcia et al. 2012). In contrast, after testing seven limes and mandarins, the percentages of infection varied between 0 and $16.3 \%$, no typical CVC symptoms developed, and occluded vessels reached a maximum of $4 \%$ in 'Cleopatra' mandarin. In 'Rangpur' lime, the most used rootstock for sweet oranges in Brazil, $X$. fastidiosa was recovered from only $1.9 \%$ of the inoculated plants, which contained only $1.1 \%$ of occluded vessels.

The nature of CVC remained unclear for a few years. With the demonstration that the disease was caused by a systemic bacterium (Chang et al. 1993) disseminated by insects (Lopes et al. 1996), disease control measures were developed and implemented. They included the following: (i) planting orchards using only healthy nursery trees produced under insect-proof facilities; (ii) sprays of field trees with insecticides to reduce vector population and to protect the trees from insect feeding; and (iii) tree removal or pruning of symptomatic branches. Pruning would work only in trees older than 3 years and if they were expressing the initial symptoms at the tip of a single branch. Then, the symptomatic branch should be removed by cutting it at least $70 \mathrm{~cm}$ below the last symptomatic leaf nearest the trunk (Beretta et al. 1996; Rodas 1994). In practice, however, pruning as recommended did not work properly, especially in orchards with a high disease incidence. Eventually, the remaining branches would show symptoms.

The negative impact of CVC on fruit production, the response of 'Rangpur' lime to $X$. fastidiosa infection, and the erratic results of pruning for re-establishing tree health motivated us to conduct a series of experiments. The objectives were to determine the extent of $X$. fastidiosa distribution in symptomatic trees, and then to assess the effectiveness of more severe pruning procedures.

\section{Materials and Methods}

A total of six experiments and six trials involving 1,733 sweet orange trees either not showing any symptoms or expressing various levels of CVC symptoms in the canopy were conducted from 2004 to 2016 at five locations in the state of Sao Paulo. The procedures are described in detail here and summarized in Table 1. 
Xylella fastidiosa distribution in symptomatic trees. When this work started, the main procedure used to detect $X$. fastidiosa in citrus was conventional PCR (Pooler and Hartung 1995) applied to DNA or xylem fluid extracted from petioles and the main veins of mature leaves. Therefore, the available protocol did not allow investigations of pathogen distribution in the lower parts of the trees, such as the main and secondary branches or trunks. During preliminary work, we successfully tested the use of conventional PCR with DNA extracted from woody tissues collected under the bark from different portions of several CVC-affected field trees or from $X$. fastidiosa pinprick-inoculated potted plants (Lopes et al. 2005) growing in the greenhouse. We also tested pathogen isolations on the periwinkle wilt $(\mathrm{PW})$, buffered charcoal yeast extract (BCYE), or phosphate charcoal yeast extract (PCYE) (Davis et al. 1981; Lopes and Torres 2006; Wells et al. 1981a) culture media. This isolation procedure proved to be too laborious and inefficient, even using leaf tissues (S. Lopes, unpublished data), mainly because of the occurrence of fast-growing contaminant bacteria. Using PCR for woody and leaf tissues, we studied $X$. fastidiosa distribution in symptomatic 'Pera' sweet orange on 'Rangpur' lime rootstock trees in two locations, namely, 60 6-year-old trees growing in two adjacent blocks (30 each) of a large farm located in Onda Verde municipality $\left(20^{\circ} 35^{\prime} 22.59^{\prime \prime} \mathrm{S}\right.$, $49^{\circ} 18^{\prime} 21.45^{\prime \prime} \mathrm{W}$ ) in northern SPS, and in more detail for 121.5 -yearold trees from a small farm located in Itápolis municipality $\left(21^{\circ} 33^{\prime}\right.$ $44.55^{\prime \prime} \mathrm{S}, 48^{\circ} 46^{\prime} 57.05^{\prime \prime} \mathrm{W}, 546 \mathrm{~m}$ ASL) in central SPS. The canopies of Onda Verde trees varied in size from $\approx 2$ to $3.5 \mathrm{~m}$ high, whereas those in Itápolis varied from 1.3 to $1.5 \mathrm{~m}$. In both cases, CVC symptom severity varied among trees. From trees of Onda Verde, samples consisted of xylem tissues obtained by scraping with an alcoholflamed knife the wood under the bark of $\approx 5$ - to 10 -cm sections of the trunk on one side of symptomatic or asymptomatic branches and scion main stems (Fig. 1A and B, Supplementary Fig. S1). From the trees of Itápolis, samples from the main trunk also included wood taken from $10 \mathrm{~cm}$ above and just below the bud union on two opposite sides, namely, one symptomatic, with the branches on the upper portion of the tree canopy expressing the typical CVC symptoms, and one asymptomatic, with upper branches free from symptoms. In addition, from the trees of this location, five leaves each from symptomatic and asymptomatic branches located $\approx 1 \mathrm{~m}$ above ground (Fig. 1B) were taken for evaluation. All leaf and wood samples were processed individually by finely chopping $0.5 \mathrm{~g}$ each and submitted to total genomic DNA extraction (do Carmo Teixeira et al. 2005) and PCR analysis (Pooler and Hartung 1995). The trees in Onda Verde were sampled in 2004, and those in Itápolis were sampled in 2005.

Pruning experiments. Pruning experiments involved a total of 200 trees used in two experiments. The trees were spread along the edges of two adjacent blocks of 6-year-old 'Pera' grafted onto 'Rangpur' lime growing in Onda Verde. The trees varied in size from $\approx 2.0$ to $3.5 \mathrm{~m}$ high, depending on the level of canopy disease severity. Of the total 100 trees of each experiment, 20 were not expressing any visible symptoms, and there were 20 at each symptom level: symptoms at the top of a single branch or in up to one-third, one-third to two-thirds, or more than two-thirds of the canopy. Pruning procedures were essentially performed as described for HLB-affected trees (Lopes et al. 2007). All upper portions of the trees were removed by cutting the main branches at their junctions, with the main stem at $\approx 60$ to $70 \mathrm{~cm}$ above soil level, or at the base of the main stem, 20 to $30 \mathrm{~cm}$ above rootstock-scion bud union (Fig. 2A to D). Trees used for Exp. 1 were pruned in May 2004, and those used for Exp. 2 were pruned in Jan. 2006. The cuts were made in a perpendicular direction to the branch main extension with a chainsaw. The wounded sites were painted with white commercial latex paint to reduce damage caused by sun exposure. The pruned trees were fertilized and sprayed regularly with insecticides and miticides, as were the remaining trees in the blocks. To further protect the new shoots from insect feeding, two to three pruned trees of each treatment were individually caged with an iron cylinder frame (length, $1.9 \mathrm{~m}$; diameter, $0.9 \mathrm{~m}$ ) (Fig. 2E to $G)$ covered with a 50 mesh $(0.78$ by $0.26 \mathrm{~mm})$ screen for the initial six months after pruning. Every 2 months, all shoots that had developed on the trunks were removed, except the four to six most
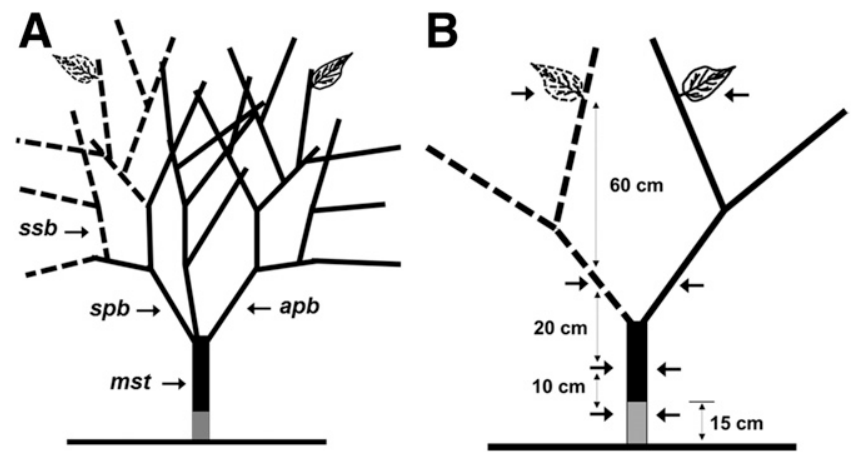

Fig. 1. Schematic representation of trees of sweet orange 'Pera' grafted onto 'Rangpur' lime rootstock (in gray) used to study Xylella fastidiosa distribution in two instances. A, 6-year-old tree sampled at various points and distances from each other (arrows). Ssb, symptomatic secondary branch; spb, symptomatic primary branches; apb, asymptomatic primary branches; and mst, main stem. B, 1.5-yearold tree sampled at distances as indicated. The main stem from this tree was also sampled above and below scion-rootstock bud union. It also included leaves taken from symptomatic (dashed lines) and asymptomatic upper branches.

Table 1. Summary of the procedures and materials used in this work to assess Xylella fastidiosa distribution in naturally infected sweet orange trees expressing the citrus variegated chlorosis disease symptoms and the effectiveness of pruning or scion substitution in trees that were asymptomatic or symptoms in variable intensities on tree canopy

\begin{tabular}{|c|c|c|c|c|}
\hline Experiment/trial & Procedures & $\begin{array}{l}\text { Scion/rootstock and } \\
\text { tree age (year) }\end{array}$ & Total trees & Location and year \\
\hline \multicolumn{5}{|c|}{ Trees not symptomatic or expressing CVC symptoms on variable portions of the canopy } \\
\hline Xylella fastidiosa distribution & $\begin{array}{l}\text { PCR applied to DNA from leaf and wood } \\
\text { tissues taken from several parts of the tree }\end{array}$ & 'Pera'/Rangpur' 6 & 60 & Onda Verde 2004 \\
\hline \multirow[t]{2}{*}{ Pruning } & $\begin{array}{l}\text { All branches cut at their junctions with the } \\
\text { main stem or at the stem base above the } \\
\text { scion-rootstock bud union }\end{array}$ & 'Pera'/Rangpur 6 & $\begin{array}{r}100,100 \\
94\end{array}$ & $\begin{array}{l}\text { Onda Verde 2004, } 2006 \\
\text { Mococa } 2007\end{array}$ \\
\hline & $\begin{array}{l}\text { Only the single branch with the early } \\
\text { symptom was cut }\end{array}$ & 'Pera'/Rangpur 6 & 72 & Mococa 2007 \\
\hline \multicolumn{5}{|c|}{ Trees highly affected by CVC and expressing symptoms on the entire canopy } \\
\hline Scion substitution & $\begin{array}{l}\text { The cut was made below the scion-rootstock } \\
\text { bud union and the newly developed shoots } \\
\text { grafted with a single healthy sweet orange } \\
\text { bud }\end{array}$ & $\begin{array}{l}\text { 'Valencia'/Rangpur } 23 \\
\text { 'Valencia'/Cleopatra } 23\end{array}$ & $\begin{array}{r}527,98 \\
76 \\
40 \\
177 \\
373\end{array}$ & $\begin{array}{l}\text { Onda Verde 2006, } 2007 \\
\text { Mococa } 2007 \\
\text { Boa Esperança do Sul } 2008 \\
\text { Conchal } 2012 \\
\text { Conchal } 2012\end{array}$ \\
\hline
\end{tabular}

\footnotetext{
y Ranpur lime (Citrus limonia Osbeck)

${ }^{\mathrm{z}}$ Cleopatra mandarin (Citrus reshni Hort. ex Tan.)
} 
vigorous shoots sprouting from the scion; every 4 months for 1 year, the selected scion shoots were assessed for the presence of CVC leaf symptoms. The effectiveness of the pruning procedure described for the experiments in Onda Verde was further tested at a farm located in Mococa, eastern SPS, in the same block where the scion substitutions were assessed. This involved 94 6-year-old adult trees of 'Pera' grafted onto 'Rangpur' lime and expressing symptoms in one-third to two-thirds of the canopies. A second group of 72 trees from the same block and expressing leaf symptoms at the top of only a single branch $\approx 2 \mathrm{~m}$ above its junction with the main stem was also selected. In this second group, only the symptomatic branch was removed by cutting it to just above its junction with the main stem.

Scion substitution trials. A total of five trials were performed at four farms located in the municipalities of Onda Verde in northern SPS $\left(20^{\circ} 33^{\prime} 39.97^{\prime \prime} \mathrm{S}, 49^{\circ} 18^{\prime} 01.41^{\prime \prime} \mathrm{W}, 548 \mathrm{~m}\right.$ ASL, same block, two trials), Boa Esperança do Sul in central SPS $\left(21^{\circ} 58^{\prime} 45.93^{\prime \prime} \mathrm{S}\right.$, $\left.48^{\circ} 20^{\prime} 27.39^{\prime \prime} \mathrm{W}, 553 \mathrm{~m} \mathrm{ASL}\right)$, and Mococa $\left(21^{\circ} 33^{\prime} 12.55^{\prime \prime} \mathrm{S}, 47^{\circ} 01^{\prime}\right.$ $53.65^{\prime \prime} \mathrm{W}, 616 \mathrm{~m}$ ASL) and Conchal $\left(22^{\circ} 12^{\prime} 44.95^{\prime \prime} \mathrm{S} 47^{\circ} 03^{\prime}\right.$ 49.36"W, $712 \mathrm{~m} \mathrm{ASL}$ ) in eastern SPS. In the first three places, 6year-old mature trees of 'Pêra' grafted onto 'Rangpur' lime were used; in Conchal, 23-year-old trees of 'Valencia' grafted onto 'Rangpur' lime or 'Cleopatra' mandarin rootstock were used. In all locations, the trees were spaced $3 \mathrm{~m}$ between trees and $6 \mathrm{~m}$ between rows. The trees, which varied in numbers between locations, were randomly selected from those already condemned by the grower to be eliminated because they were expressing severe and extensive symptoms of CVC on leaves and fruit throughout the canopy. The symptoms were characterized by wilted and chlorotic leaves, and small, hard, yellow fruit. Before pruning, the infected trees were approximately two-thirds the size of those free from CVC or expressing the initial disease symptoms, which indicated that they probably had been infected years before. All upper portions of the trees were removed, as described for the pruning experiments, except that the cuts were made below the scion-rootstock bud union or just above in those trees on which the bud union was just below the soil level. Pruning height varied from 5 to $15 \mathrm{~cm}$ above ground. The remaining trunk was then painted with white latex ink, as in the pruning experiments.

In Onda Verde, using the same cages used in the pruning experiments, 23 rootstock trunks of trial 1 were screen-caged as indicated. The trunks were observed periodically, and most newly developed shoots sprouting from the rootstock, as well as all those that sprouted from the small sections of scion stem that remained after pruning, were removed. Only the three to four most vigorous shoots that sprouted from each rootstock trunk were allowed to grow. Four months later, shoot diameter was $\approx 1 \mathrm{~cm}$ at the base. Then, a single healthy bud of the same scion cultivar ('Pera') was side-grafted on each shoot, 30 to $40 \mathrm{~cm}$ above its junction with the trunk. The clear plastic budding tape that was used to fix the bud onto the shoot was removed 30 days later. Six weeks later, using an alcohol-flamed pruning shear, the rootstock shoot portion above the bud graft was removed by cutting it $5 \mathrm{~cm}$ above the bud site. To avoid wound
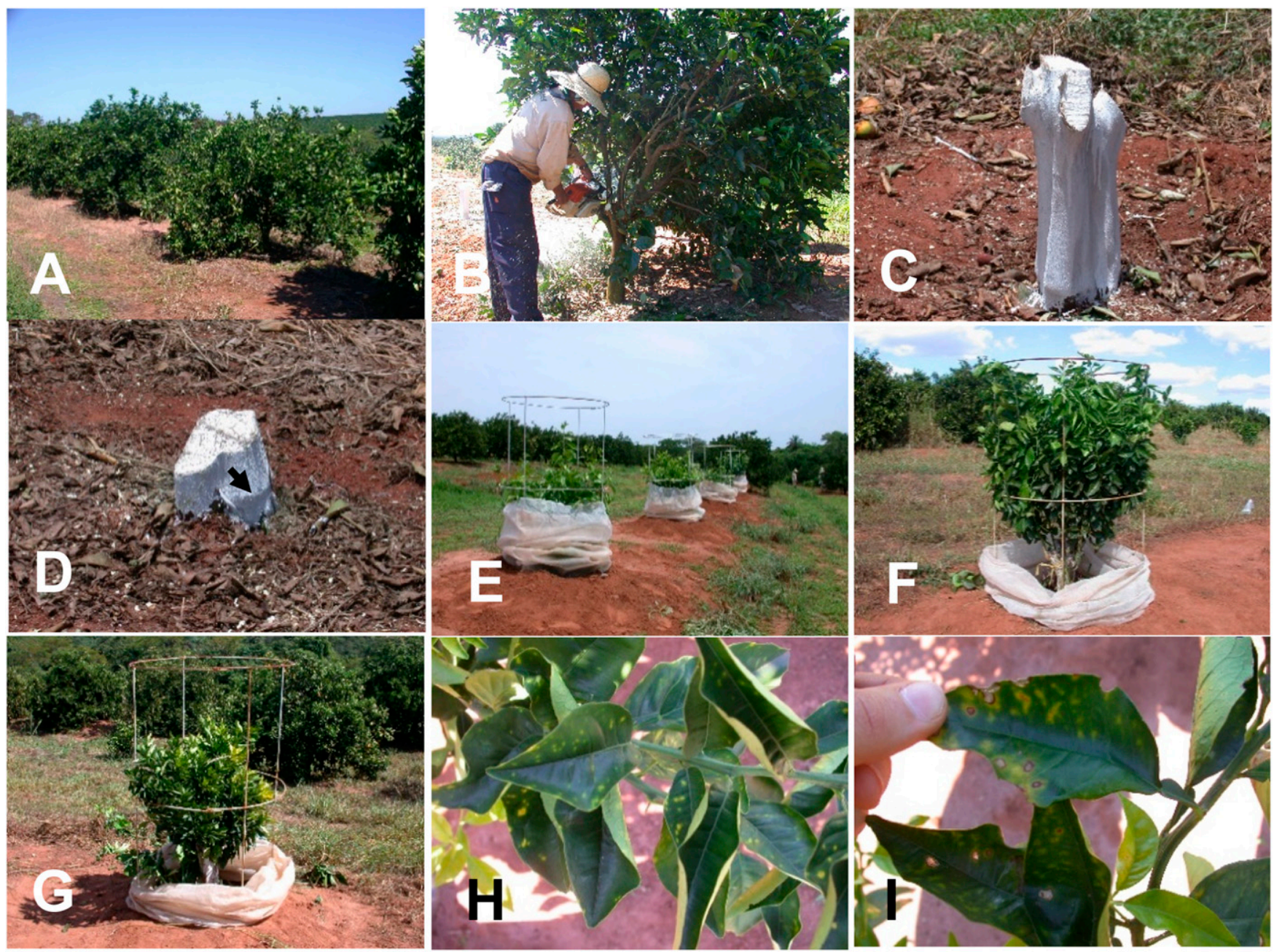

Fig. 2. Photographic description of the main steps of the pruning experiments involving 6-year-old 'Pera' sweet orange trees affected or not by citrus variegated chlorosis (CVC) disease. A, A tree severely affected by CVC disease before pruning (front right). B, Initial step of pruning. C, A trunk from which the main branches had been removed. D, A trunk cut above bud union (arrow). E, Aspect of trees caged with metal frames, with the screen lowered to favor leaf symptom evaluation. F, An asymptomatic tree at 4 months after pruning. G, A symptomatic tree 4 months after pruning. $\mathrm{H}$, Early stage of CVC symptoms on leaves. I, Late stage of CVC symptoms. 
infection by other pathogens, the cut surfaces of trees in trial 2 in Onda Verde and of all trees of the trials in the other locations were brushed with $0.25 \mathrm{~kg} /$ liter of water of Kocide $(53.8 \%$ copper hydroxide; Mitsui, Brazil). Then, the new scions were allowed to grow to form new canopies. In Onda Verde, the new scions remained caged for an additional 6 months when the cages were removed to not interfere with shoot growth. On all farms, the grower regularly fertilized and sprayed the scion-substituted trees similarly to the remaining unpruned trees or newly planted young trees to protect against insect and mite pests. As performed previously, all undesirable new shoots that had developed on the rootstock portion were removed every 4 to 5 weeks after bud grafting. At 5 and 10 months after grafting, and at varying periods depending on the location, the new scions were observed for the presence of CVC symptoms on mature leaves or of any other citrus disease. In Onda Verde, the width and height dimensions of the canopy of the newly developed scions and of several unpruned or replanted trees were evaluated 5.5 years (trial 1) and 4.8 years (trial 2) after bud grafting or 5.0 to 5.5 years from the planting date. The canopy volume was estimated using the formula:

$$
\mathrm{V}=2 / 3 \times \pi \times \mathrm{R}^{2} \times \text { height }
$$

In Boa Esperança do Sul, in addition to tree dimension, fruit weight and number were evaluated 3.5 years after bud grafting in the scionsubstituted trees (Fig. 3).

Data analysis. No statistical procedures were applied to data from the study to determine $X$. fastidiosa distribution within the canopies of symptomatic trees or from the scion substitution trials. The data from pruning were used for the $\chi^{2}$ test to compare treatments within experiments, with Yate's correction when expected frequencies were $<5(P<0.05)$. Data from tree dimensions were
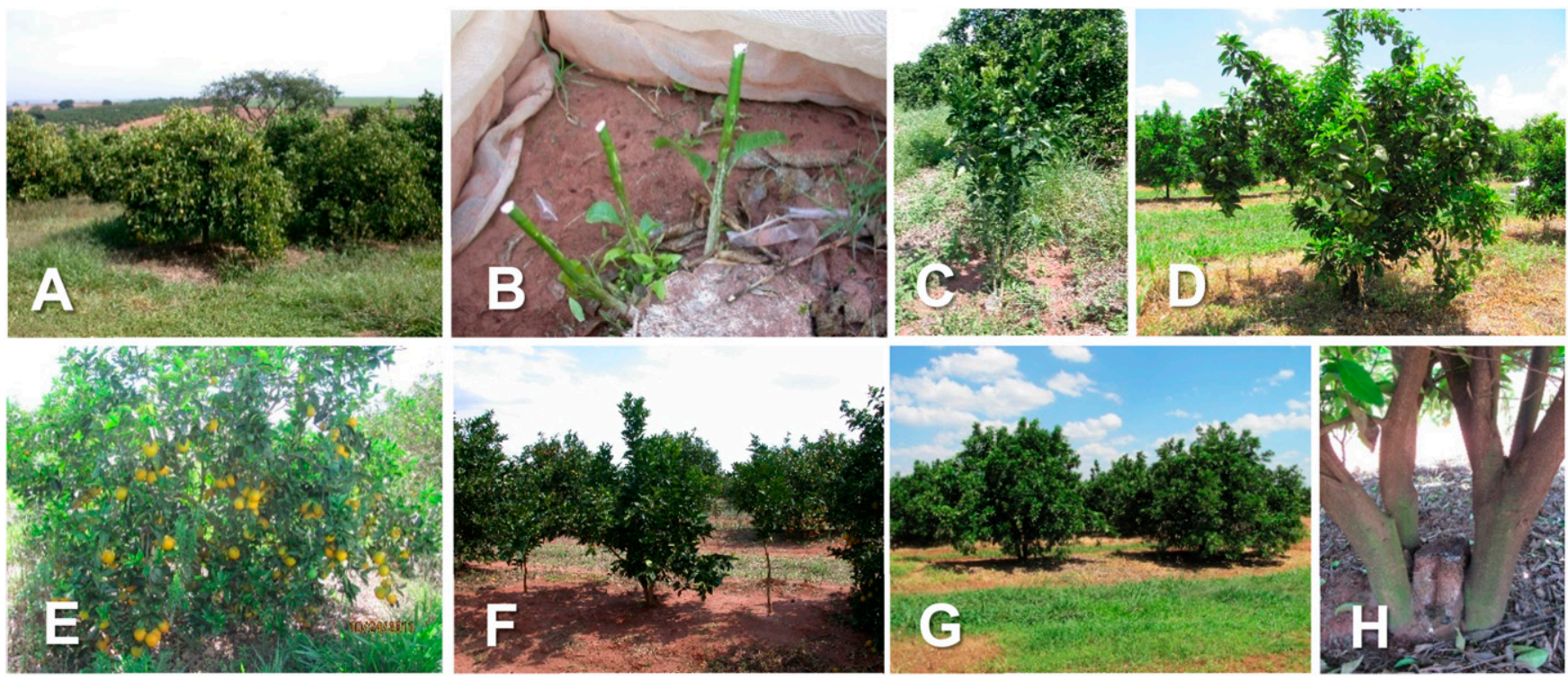

Fig. 3. Photographic description of the main steps of pruning citrus variegated chlorosis-affected trees at the rootstock level followed by scion substitution, and aspects of young and old new scions of 'Pera' sweet orange growing on 'Rangpur' lime rootstock. A, A tree highly affected by the disease before pruning. B, New 'Rangpur' shoots 5 months after pruning and just after upper shoot removal (see the grafted buds). C, Young new scion 3 months after grafting. D, A 2-year-old new scion starting fruit production. E, A 3.5-year-old tree at harvest time. F, A scion-substituted tree near replanted trees (to the left and to the right) at $\approx 1$ year after bud grafting or planting. G, A healthy-looking scion-substituted tree 4.5 years after bud grafting (to the left) and a regularly planted 10.5-year-old asymptomatic tree. $\mathbf{H}$, Close-up of the main stems of the new scions of the scion-substituted tree shown in $\mathbf{G}$

Table 2. Frequency of citrus stems from adult trees of 'Pera' sweet orange grafted on 'Rangpur' lime with newly developed shoots exhibiting symptoms of citrus variegated chlorosis disease 12 months after total canopy removal by cutting the trees at the base of the main stem or near its junction with the primary branches

\begin{tabular}{|c|c|c|c|c|}
\hline \multirow[b]{3}{*}{ Plant status before pruning } & \multicolumn{4}{|c|}{ Pruning sites } \\
\hline & \multicolumn{2}{|c|}{ Experiment 1} & \multicolumn{2}{|c|}{ Experiment 2} \\
\hline & Base of main stem $^{x}$ & Stem-branch junctures $^{\mathbf{y}}$ & Base of main stem ${ }^{x}$ & Stem-branch junctures $^{y}$ \\
\hline No symptoms & $0 / 7(0)$ & $3 / 10(0.3)$ & $0 / 8(0)$ & $2 / 10(0.2)$ \\
\hline Symptoms ${ }^{\mathrm{z}}$ in one secondary branch & $0 / 10(0)$ & $7 / 10(0.7)$ & $0 / 8(0)$ & $2 / 10(0.2)$ \\
\hline $\begin{array}{l}\text { Symptoms in one primary branch } \\
\text { ( } \leq \text { one-third canopy) }\end{array}$ & $1 / 7(0.14)$ & $9 / 10(0.9)$ & $1 / 8(0.13)$ & $4 / 10(0.4)$ \\
\hline $\begin{array}{l}\text { Symptoms in one-third to two-thirds } \\
\text { of the canopy }\end{array}$ & $1 / 7(0.14)$ & $10 / 10(1)$ & $2 / 9(0.22)$ & $5 / 6(0.83)$ \\
\hline Symptoms in >two-thirds of the canopy & 0/7 (0) & 9/9 (1) & $0 / 9(0)$ & $8 / 9(0.89)$ \\
\hline Averages & $2 / 38(0.05)$ & $38 / 49(0.78)$ & $3 / 42(0.07)$ & $21 / 45(0.47)$ \\
\hline Chi square & \multirow{2}{*}{\multicolumn{2}{|c|}{$\begin{array}{l}45.027 \\
<0.0001\end{array}$}} & \multirow{2}{*}{\multicolumn{2}{|c|}{$\begin{array}{l}16.988 \\
<0.0001\end{array}$}} \\
\hline$P$ value & & & & \\
\hline
\end{tabular}

${ }^{\mathrm{x}}$ Cut performed perpendicularly at the trunk 20 to $30 \mathrm{~cm}$ above the scion-rootstock bud union.

${ }^{y}$ Cut performed at the base of the primary branches near their junctures with the main stem. In Exp. 1, two base-pruned stems and one juncture-pruned stem died completely. Shoots developed only at the 'Rangpur' lime portion of the trunk of 10 trees. In Exp. 2, three base-pruned stems died. Also, in five trunks of this treatment and in one juncture-pruned stem, only shoots of 'Rangpur' lime developed.

${ }^{\mathrm{z}}$ Yellow, gummy spots on leaf blade (also includes hard, small, yellow fruits in trees affected in one primary branch). 
used for the analysis of variance, followed by a mean comparison (Tukey test, $P<0.05$ )

\section{Results}

Xylella fastidiosa distribution in symptomatic trees. The pathogen was found more frequently on the symptomatic side and in the upper canopy of the trees from both locations. In the two blocks of Onda Verde, $X$. fastidiosa was detected in 23 and 17 samples (77 and $57 \%$, respectively) from symptomatic secondary branches, in 21 and 12 (70 and 40\%, respectively) from primary branches of the same symptomatic side, in 15 and 6 (50 and 20\%, respectively) from the main scion stem, and from 13 and 12 (43 and 40\%, respectively) from the primary branches of the asymptomatic side of the trees. The pathogen was not detected at any site of four or five trees of each block (Supplementary Table S1), probably as a result of its irregular distribution in plant tissues. In Itápolis, X. fastidiosa was detected in 17 of $20(85 \%)$ samples from symptomatic branches, in 6 of $26(23 \%)$ samples from asymptomatic branches, in 2 of $24(8 \%)$ samples from the main trunk above bud union, and in 4 of 24 (17\%) samples from the main trunk below bud union (Supplementary Fig. S2). Under ultraviolet (UV) light, most amplified DNA from the lower parts of the trees resulted in faint fluorescent bands in agarose gels; these results were confirmed with a second PCR.

Pruning experiments. During both experiments conducted in Onda Verde, new shoots developed at the stem-branch junctions of most pruned trees (Fig. 2E to G). However, for those trees on which the scion was cut at the base of the stem, a few trunks died, and for several trees only the rootstock portion of the trunk survived and grew shoots. These shoots from the rootstock did not express any CVC symptoms throughout the 1 year during which the experiment was conducted.

On the shoots that sprouted from the scion, the first characteristic CVC symptoms, namely, wilted leaves (Fig. 2G) with small, yellow, gummy spots (Fig. 2H), were visible on many pruned trees at $\approx 4$ months after pruning. Symptoms progressed to extensive yellowing and necrotic leaves (Fig. 2I) on most shoots and affected shoot development. At the end of the experiment, symptomatic shoots (Fig. 2G) had reached one-half to two-thirds the size of those not showing any symptoms (Fig. 2F). No influence of caging on symptom expression and incidence was observed. The overall percentages of symptomatic scions were 48.4 in caged and 41.4 in noncaged trunks 1 year after pruning.

Pruning success, namely, the proportion of scions that did not develop symptoms, was clearly influenced by the height at which the stem had been cut in both experiments (Experiment 1: $\chi^{2}=$ 45.027, $P<0.0001$; Experiment $\left.2: \chi^{2}=16.988, P<0.0001\right)$ (Table 2). A much lower incidence of symptoms was observed for trees cut at the base of the stem (5 and 7\%, respectively) than for those cut at the stem-branch junctions ( 78 and $47 \%$, respectively). For the trees that had been cut at the stem-branch junctions, the

Table 3. Timewise distribution according to symptom category of new scions of 'Pera' or 'Valencia' that developed on new shoots of 'Rangpur' lime or 'Cleopatra' mandarin rootstock after complete removal of the same scion variety of 6-year-old trees severely affected by citrus variegated chlorosis disease

\begin{tabular}{|c|c|c|c|c|c|c|c|}
\hline \multirow[b]{2}{*}{ Orange/rootstock varieties } & \multirow[b]{2}{*}{ Location, date, and grafted ${ }^{\mathrm{x}}$ trees } & \multirow{2}{*}{$\begin{array}{c}\text { Time after } \\
\text { grafting }(\mathbf{m o})^{\mathrm{y}}\end{array}$} & \multicolumn{4}{|c|}{$\begin{array}{l}\text { Number of trees in } \\
\text { each symptom } \\
\text { categoryz }\end{array}$} & \multirow{2}{*}{$\begin{array}{c}\text { Percentage of symptomatic } \\
\text { new scions }(\%)\end{array}$} \\
\hline & & & $\mathbf{0}$ & 1 & 2 & 3 & \\
\hline \multirow[t]{10}{*}{ 'Pera'/'Rangpur' lime } & Onda Verde, Apr. 2006, 173 & $5,10,21$ & 169 & 1 & 1 & 2 & 2.3 \\
\hline & & 26 & 167 & 1 & 2 & 3 & 3.5 \\
\hline & & 37 & 161 & 0 & 8 & 4 & 6.9 \\
\hline & & 47 & 147 & 14 & 8 & 4 & 15.0 \\
\hline & Onda Verde, Feb. 2007, 79 & $5,10,20,24$ & 79 & 0 & 0 & 0 & 0 \\
\hline & & 36 & 77 & 0 & 2 & 0 & 2.5 \\
\hline & Mococa, Oct. 2007, 76 & $6,10,15$ & 76 & 0 & 0 & 0 & 0 \\
\hline & & 26 & 74 & 0 & 2 & 0 & 2.6 \\
\hline & & 32 & 64 & 4 & 4 & 2 & 13.2 \\
\hline & Boa Esperança do Sul, Apr. 2008, 30 & $5,10,20,25,42$ & 37 & 0 & 0 & 0 & 0 \\
\hline \multirow[t]{4}{*}{ 'Valencia'/'Rangpur' lime } & Conchal, May to Dec. 2012, 175 & 5,10 & 175 & 0 & 0 & 0 & 0 \\
\hline & & 25 & 174 & 0 & 0 & 1 & 0.6 \\
\hline & & 30,34 & 171 & 2 & 0 & 4 & 3.4 \\
\hline & & 38 & 168 & 1 & 2 & 4 & 4.0 \\
\hline \multirow[t]{2}{*}{ 'Valencia'/'Cleopatra' mandarin } & Conchal, May to Dec. 2012, 130 & 5,10 & 130 & 0 & 0 & 0 & 0 \\
\hline & & $25,30,34,38$ & 128 & 0 & 0 & 2 & 1.5 \\
\hline
\end{tabular}

${ }^{x}$ The main stem was perpendicularly cut with a chainsaw just above the rootstock-scion bud union.

y One healthy bud of 'Pera' or 'Valencia' sweet orange side-grafted on each of the three to four shoots that grew on the rootstock trunk 4 months after tree decapitation.

${ }^{\mathrm{z}} 0=$ no symptoms (yellow, gummy spots on leaf blade); $1=$ symptoms at the top of only one secondary branch; $2=$ symptoms fully distributed throughout at least one primary branch but no more than two-thirds of the tree canopy; and $3=$ symptoms in more than two-thirds of the tree canopy.

Table 4. Canopy dimensions of 'Pera' sweet orange scions of various ages growing on 'Rangpur' lime rootstock of regularly planted or replanted trees or on the bud-grafted replacement shoots (new scions) that developed on the rootstock trunk of fully decapitated highly infected adult trees in an orchard in Onda Verde, northern Sao Paulo State, Brazil

\begin{tabular}{lccccc}
\hline Canopy & Age (years) & Total & Height $(\mathbf{m})$ & Width $(\mathbf{m})$ & Volume $\left(\mathbf{m}^{\mathbf{3}}\right)$ \\
\hline Healthy, regular planting & 12.5 & 50 & $3.62 \pm 0.04 \mathrm{a}$ & $4.53 \pm 0.05 \mathrm{a}$ & $39.01 \pm 0.90 \mathrm{a}$ \\
Diseased, regular planting & 12.5 & 50 & $3.12 \pm 0.04 \mathrm{c}$ & $3.95 \pm 0.06 \mathrm{~b}$ & $25.83 \pm 0.94 \mathrm{~b}$ \\
Healthy, new scion & 5.5 & 144 & $3.34 \pm 0.03 \mathrm{~b}$ & $3.56 \pm 0.04 \mathrm{c}$ & $22.93 \pm 0.65 \mathrm{~b}$ \\
Healthy, regular replanting & 5 to 5.5 & 48 & $3.48 \pm 0.04 \mathrm{a} \mathrm{b}$ & $3.44 \pm 0.06 \mathrm{c} \mathrm{d}$ & $21.92 \pm 0.82 \mathrm{~b} \mathrm{c}$ \\
Healthy, new scion & 4.8 & 46 & $3.05 \pm 0.08 \mathrm{c}$ & $3.32 \pm 0.06 \mathrm{~d}$ & $18.31 \pm 1.07 \mathrm{c}$ \\
$\mathrm{F}_{4,333}$ & & & 19.96 & 61.73 & 63.94 \\
$P$ value & & & $<0.0001$ & $<0.0001$ & $<0.0001$ \\
\hline
\end{tabular}

${ }^{\mathrm{z}}$ Means followed by the same letter are not significantly different at the indicated $P$ value. 
lower the symptom severity before pruning, the higher the pruning efficacy.

Pruning effectiveness was further tested in a new location (Mococa), with 94 trees exhibiting symptoms on one-third to twothirds of canopies. Three trunks died and CVC was detected in 42 (44.7\%) of the remaining 91 pruned trees. In the same block, a second set of trees with early CVC symptoms were also pruned but, in this case, only by removing the symptomatic branch. Huanglongbing symptoms, which were shown by PCR (Li et al. 2006) to be associated with infection with Candidatus Liberibacter asiaticus, appeared on three trees 4 months after pruning and were eliminated. One year after pruning, 22 trees (31.9\%) were expressing CVC symptoms on at least one branch.

Scion substitution trials. The lack of effectiveness of symptomatic branch removals for re-establishing tree health, the high mortality of the remaining stems from severely pruned trees, and the vigorous development of healthy-looking 'Rangpur' lime shoots in several surviving stems motivated us to test the possibility of reusing the rootstock of highly CVC-affected trees to produce new healthy and productive scions. The study involved 527 and 98 trees in Onda Verde (trials 1 and 2), 76 trees in Mococa, 40 trees in Boa Esperança do Sul, and 177 and 373 trees (trials 1 and 2) in Conchal ('Valencia' on 'Rangpur' lime or 'Cleopatra' rootstock). Most 6-year-old 'Rangpur' lime rootstocks survived and emitted new shoots (Fig. 3C to $\mathrm{H}$ ) in all four locations as soon the graft wraps that covered the bud were removed. The 23-year-old trees in Conchal had irregular shoot production. In addition, on 'Cleopatra', 243 trunks (65\%) died. In Mococa, shoots from 18 rootstock trunks had to be regrafted with new buds.

During trial 1 at Onda Verde, a few weeks after bud grafting, several shoots showed necrosis, which started at the cut site above the graft location. The necrotic lesion progressed downward, leading to the death of the grafted shoots grown on nearly two-thirds (67.2\%) of all trunks. This problem was solved with the use of copper hydroxide; during the other trial performed later in the same block (trial 2) and at other farms where copper hydroxide was used, most scion buds developed and formed new canopies. At the last evaluation date, an average of 1.3 to 2.2 new scions had developed on each trunk in all locations. Probably because of competition for space, the higher the number of scions in the same trunk, the lower the stem diameter.

Except in Boa Esperança do Sul, where no scion expressed symptoms during the entire period when the trees were observed, a similar pattern of symptom occurrence was detected (Table 3). During the first trial in Onda Verde, leaf symptoms were observed in four trees $(2.3 \%)$ at the first evaluation date 5 months after bud graft, with one showing the initial, one showing the intermediate, and two showing the severe stage of CVC symptoms (Fig. 3A). The incidence of the disease increased to $3.5,6.9$, and $15.0 \%$, at 26,37 , and 47 months, respectively, after bud graft. During the second trial at this location, and during the trials in Mococa and Conchal, the first CVC symptoms appeared 2 years after bud grafting, reaching maximums of $2.5,13.2$, and $4.0 \%$ respectively (Table 2 ). Three trees in Boa Esperança do Sul and one in Mococa became infected and expressed symptoms of HLB and were eliminated.

In Onda Verde, at the time of the experiment and during the months thereafter, several fully symptomatic trees not used in the trials were removed from the block and replanted in the same row locations with new healthy young plants (Fig. 3F), which is a practice followed by most growers attempting to minimize the negative impact of CVC on fruit production. In November 2011, the height and width of the canopies of 144 and 46 new scions of the rootstock-pruned trees of trial 1 and trial 2, respectively, were compared with those of 48 replanted trees and with 50 healthy and 50 fully symptomatic trees that remained in the blocks since the start of the trials (original plantings). Therefore, when the canopies were evaluated, the ages were $5.5,4.8,5.0$ to 5.5 , and 12.5 years, respectively, for the trees in trial 1 , trees used in trial 2, replantings, and original plantings.

When trees were of similar ages, the average canopy volume of the new scions of the trees in trial $1\left(22.93 \pm 0.65 \mathrm{~m}^{3}\right)$ or trial $2(18.31 \pm$
1.07) did not differ statistically from that of the healthy trees that were replanted $(21.92 \pm 0.82)$. The canopy volume of the trees in trial 1 also did not differ from that of the originally planted fully symptomatic trees that were 7 years older $(25.83 \pm 0.94)$, but it was $41 \%$ smaller than that of the original trees $(39.01 \pm 0.90)$ that were not expressing any symptoms. When trees were 8 months younger than the trees in trial 1, the average canopy volumes of the new scions of trial 2 were 53 and $29 \%$, respectively, smaller than those of the healthy and fully symptomatic originally planted trees that were 7.7 years older (Table 4 ).

The dimension of new scions of the 31 healthy trees at the Boa Esperança do Sul farm also were measured 3.5 years after scion substitution. Figure $3 \mathrm{E}$ shows the aspect of a tree at harvest time in this location. Canopy volumes averaged $13.22 \pm 5.28 \mathrm{~m}^{3}$. Two trees had no fruit (had already been harvested by the grower), and for 5, 10, 7, and 7 trees, the fruit weighed between 0.6 and 9.1, 13.2 and 28.8, 33.1 and 40.2 , and 42.8 and $85.7 \mathrm{~kg}$, respectively.

\section{Discussion}

This work was performed to improve the effectiveness of pruning to control CVC. The occurrence of the disease in nearly one-third of the pruned trees in Mococa, from which the symptomatic branch had been removed, confirmed previous field observations. To proceed with the investigations, it was useful to know the extent of tree colonized by the pathogen; therefore, a protocol to detect $X$. fastidiosa in woody tissues was necessary. Several attempts to isolate $X$. fastidiosa on solid culture media failed. A great number of fast-growing bacterial contaminants commonly found in citrus tree xylem (Lacava et al. 2004) appeared on plates. After determining the suitability of extracting DNA from woody tissues to be used for the PCR, this method was chosen to analyze hundreds of samples from naturally infected trees with different ages and variable levels of symptom severity. Probably because of the earlier and higher number of infection events that resulted from $X$. fastidiosa-carrying sharpshooter feedings, the bacterium was found to be more widely distributed in the older trees, which included the main stem and asymptomatic branches, than in the younger trees, in which the pathogen was concentrated in the upper portions of the symptomatic branches.

The PCR protocol used in this work did not discriminate DNAs from live and dead cells. Therefore, it was possible that, in many instances, the detected bacterium, mainly those found in the older main stem, could have been nonviable. However, the high incidence of symptoms on the newly developed scions of branch-decapitated symptomatic trees proved that, at least in the upper main stem, near its junction with the main branches, live cells were present, which would limit the use of branch decapitation to control CVC. CVC symptoms also appeared in 20 to $30 \%$ of trunks from previously asymptomatic trees, revealing that in orchards with a high incidence of diseased trees, the occurrence of latent infections is much more frequent than suspected. In the pruning experiments, the main stems were also cut down on the trunk, 20 to $30 \mathrm{~cm}$ above the scion-rootstock bud union. A lower incidence of shoots with symptoms developed. However, the results were erratic and the severe pruning procedure killed 20 to $30 \%$ of the remaining scions, forcing the emergence of only the undesirable rootstock shoots.

In other work, it was demonstrated that 'Rangpur' lime, the most used rootstock in Brazil, is highly resistant to CVC (Garcia 2006; Garcia et al. 2012), which was confirmed by this work. The new 'Rangpur' lime shoots from trunks of highly CVC-affected trees developed free from symptoms, thereby creating an opportunity to be used to start a new healthy tree with the use of healthy sweet orange buds from certified sources. This hypothesis was tested during six trials at four locations. No or a very low incidence of disease was observed on the new scions that developed from the grafted bud during the first months after grafting. The incidence increased over time. However, because of new infections caused by infectious sharpshooters, and not because of failure of the scion substitution method, in most canopies, CVC first appeared at least 2 years after grafting. The method seemed to have failed for only 2 of 173 cases $(1.2 \%)$ in the first trial in Onda Verde, with the new scions becoming 
fully symptomatic at the first evaluation date 5 months after bud grafting.

The scion substitution method was tested at one farm and also with 23-year-old sweet oranges growing on 'Rangpur' lime or 'Cleopatra' mandarin. Although the percentage of healthy scions produced on 'Cleopatra' was even higher than those on 'Rangpur' lime, 'Cleopatra' was found to be more sensitive than 'Rangpur' to the severe pruning procedure, with most trunks dying after decapitation. Because younger trees on 'Cleopatra' were not tested, we could not determine whether the cause would be the age of the trees. The trees on this rootstock could also be affected by some undiagnosed root disease, like Phytophthora root rot, which was aggravated by the pruning procedure, leading to death of the pruned trunks.

The volumes of the canopies of the scion-substituted trees were compared with those of trees that had been planted in the same block during the same time period. Visual observation indicated that the scion-substituted trees grew faster than the replanted trees during the first years, but they reached similar canopy volumes at 5 years of age. The faster initial growth of scion-substituted trees was followed by earlier fruit production. Fruit were observed at $\approx 2$ years, reaching $>80 \mathrm{Kg}$ per tree in the third year in Boa Esperança do Sul. A comparison of canopy volumes of the originally planted trees also confirmed how damaging CVC can be to the production of sweet orange (Ayres 2000). The healthy-looking canopies were, on average, 1.5-times bigger than those of trees highly affected by the disease.

In this work, we demonstrated that removal of symptomatic branches of CVC-affected trees is not sufficiently effective for controlling the disease, at least in areas of diseased tree incidences $>5 \%$ as were the farms where the experiments were performed. Pruning was not effective or advantageous even when the cut was made at the trunk level, above the bud union. The recommendation is that, in partially affected orchards, the highly affected trees should be eliminated and replaced by new, healthy, young trees. However, we demonstrated that they do not need to be totally removed. Their rootstock can be reused to form a new and healthy canopy at a total cost that was estimated to be one-third of that for new tree acquisition and replanting during the first year. The new scions grew faster than the new plantings and free from CVC, probably because of a greater supply of water, minerals, and carbohydrates provided by the expanded and deeper root system. Therefore, this new strategy to control CVC might be of interest, especially to small and less technologically equipped farmers.

\section{Acknowledgments}

I thank the farmers for allowing us to conduct this work on their properties, and Dr. Juan C. Cifuentes-Arenas for statistical analysis of the data.

\section{Literature Cited}

Ayres, A. J. 2000. Intensidade da clorose variegada dos citros em pomares comerciais de laranja do Estado de São Paulo e Sul do Triângulo Mineiro. MSc Thesis, Universidade Estadual Paulista, Faculdade de Ciências Agrárias e Veterinárias, Jaboticabal, SP, Brasil.

Beretta, M. J. G., Rodas, V., Garcia, A., Junior., and Derrick, K. S. 1996. Control of citrus variegated chlorosis by pruning, Pages 378-379 in: Proc. 13th Conf. Int. Org. Citrus Virol. Riverside, CA.

Chang, C. J., Garnier, M., Zreik, L., Rossetti, V., and Bové, J. M. 1993. Citrus variegated chlorosis: Cultivation of the causal bacterium and experimental reproduction of the disease, Pages 294-300. Proc. 12th Conf. Int. Org. Citrus Virol. Riverside, CA.

Contreras, J. D. V. 1992. Pecosita ou falsa mancha grasienta na Argentina. Laranja e Cia 31:6.

Davis, M. J., French, W. J., and Schaad, N. W. 1981. Axenic culture of the bacteria associated with phony disease of peach and plum leaf scald. Curr. Microbiol. 6: 309-314.

Davis, M. J., Purcell, A. H., and Thomson, S. V. 1978. Pierce's disease of grapevines: isolation of the causal bacterium. Science 199:75-77.

Fundecitrus. 2018a. Tree inventory of São Paulo and west-southwest Minas Gerais citrus belt: snapshot of groves in March 2018. https://www.fundecitrus.com.br/ pdf/pes_relatorios/Tree_Inventory_and_Orange_Crop_Forecast_2018-2019.pdf
Fundecitrus. 2018b. Levantamento da incidência de doenças dos citros: Greening, CVC e Cancro Cítrico 2017. https://www.fundecitrus.com.br/pdf/levantamentos/ LevantamentoDeDoencas2018-greening-cvc-cancroCitrico.pdf.

Garcia, A. L. 2006. Quantificação de parâmetros patológicos envolvidos en interações citros/Xylella fastidiosa. M. Sc. Thesis. Universidade de Ribeirão Preto, $67 \mathrm{p}$.

Garcia, A. L., Torres, S. C. Z., Heredia, M., and Lopes, S. A. 2012. Citrus responses to Xylella fastidiosa infection. Plant Dis. 96:1245-1249.

Gravena, S., Lopes, J. R. S., Paiva, P. E. B., Yamamoto, P. T., and Roberto, S. R. 1998. Pages 37-53 in: Os vetores da Xylella fastidiosa. Clorose Variegada dos Citros. L. C. Donadio, and C. S. Moreira, eds. Fundecitrus, Bebedouro, Brazil.

Hewitt, W. B., Frazier, N. W., Jacob, H. E., and Freitag, J. H. 1942. Pierce's disease of grapevines. University of California, College of Agriculture, Agricultural Experiment Station. Berkeley, California

Lacava, P. T., Araújo, W. L., Marcon, J., Maccheroni, W., Jr., and Azevedo, J. L. 2004. Interaction between endophytic bacteria from citrus plants and the phytopathogenic bacterium Xylella fastidiosa, causal agent of citrus variegated chlorosis. Lett. Appl. Microbiol. 39:55-59.

Lee, R. F., Beretta, M. J. G., Hartung, J. H., Hooker, M. E., and Derrick, K. S. 1993. Citrus variegated chlorosis: confirmation of Xylella fastidiosa as the causal agent. Summa Phytopathol. 19:123-125.

Li, W., Hartung, J. S., and Levy, L. 2006. Quantitative real-time PCR for detection and identification of Candidatus Liberibacter species associated with citrus huanglongbing. J. Microbiol. Methods 66:104-115.

de Lima, J. E. O., Miranda, V. S., Hartung, J. S., Brlansky, R. H., Coutinho, A., Roberto, S. R., and Carlos, E. F. 1998. Coffee leaf scorch bacterium: Axenic culture, pathogenicity, and comparison with Xylella fastidiosa of citrus. Plant Dis. 82:94-97.

Lopes, J. R. S. 1996. Mecanismo de transmissão de Xylella fastidiosa por cigarrinhas. Laranja 17:79-92.

Lopes, J. R. S., Beretta, M. J. G., Harakawa, R., Almeida, R. P. P., Krügner, R., and Garcia-Junior, A. 1996. Confirmação da transmissão por cigarrinhas do agente causal da clorose variegada dos citros, Xylella fastidiosa. Fitopatol. Bras. 21:343.

Lopes, S. A., Frare, G. F., Yamamoto, P. T., Ayres, A. J., and Barbosa, J. C. 2007 Ineffectiveness of pruning to control citrus huanglongbing caused by Candidatus Liberibacter americanus. Eur. J. Plant Pathol. 119:463-468.

Lopes, S. A., Laranjeira, F. F., Amorim, L., and Bergamin Filho, A. 2004. Clorose variegada: perdas anuais de US\$ 100 milhões. Visão Agrícola. 1:20-23.

Lopes, S. A., Teixeira, D. C., Fernandes, N. G., and Ayres, A. J. 2005. An experimental inoculation system to study citrus- Xylella fastidiosa. Plant Dis. 89:250-254.

Lopes, S. A., and Torres, S. C. Z. 2006. An effective and low cost medium for isolation of Xylella fastidiosa from citrus and coffee plants. Curr. Microbiol. 53:467-469.

Paradela Filho, O., Sugimori, M., Ribeiro, I., Garcia, A., Beretta, M., Harakava, R. Machado, M., Laranjeira, F., Rodrigues Neto, J., and Beriam, L. 1997. Constatação de Xylella fastidiosa em cafeeiro no Brasil. Summa Phytopathol. 23:46-49.

Pooler, M. R., and Hartung, J. S. 1995. Specific PCR detection and identification of Xylella fastidiosa strains causing citrus variegated chlorosis. Curr. Microbiol. 31:377-381.

Purcell, A. H., Saunders, S. R., Hendson, M., Grebus, M. E., and Henry, M. J. 1999. Causal role of Xylella fastidiosa in oleander leaf scorch disease. Phytopath. 89:53-58

Redak, R. A., Purcell, A. H., Lopes, J. R. S., Blua, M., Mizell, R. F., III, and Anderson, P. C. 2004. The biology of xylem-fluid-feeding insect vectors of Xylella fastidiosa and their relation to disease epidemiology. Annu. Rev. Entomol. 49:243-270

Rodas, V. 1994. Convivência com a clorose variegada dos citros. Laranja 15: 129-134.

Rossetti, V., and De Negri, J. 1990. Clorose variegada dos citros: revisão. Laranja $11: 1-14$

Rossetti, V., Garnier, M., Bové, J. M., Beretta, M. J. G., Teixeira, A. R. R., Quaggio, J. A., and De Negri, J. D. 1990. Présence de bactéries dans le xylème d'orangers atteints de chlorose variégé, une nouvelle maladie des agrumes au Bresil. C. R. Acad. Sci. Ser. III. 30:345-349.

Saponari, M., Boscia, D., Nigro, F., and Martelli, G. P. 2013. Identification of DNA sequences related to Xylella fastidiosa in oleander, almond and olive trees exhibiting leaf scorch symptoms in Apulia (southern Italy). J. Plant Pathol. 95:668.

do Carmo Teixeira, D., Danet, J. L., Eveillard, S., Martins, E. C., Jesus, W. C., Junior., Yamamoto, P. T., and Bové, J. M. 2005. Citrus huanglongbing in São Paulo State, Brazil: PCR detection of the Candidatus Liberibacter species associated with the disease. Mol. Cell. Probes 19:173-179.

Wells, J. M., Raju, B. C., Nyland, G., and Lowe, S. K. 1981a. Medium for isolation and growth of bacteria associated with plum leaf scald and phony peach diseases. Appl. Environ. Microbiol. 42:357-363.

Wells, J. M., Raju, B. C., Thompson, J. M., and Lowe, S. K. 1981b. Etiology of phony peach and plum leaf scald diseases. Phytopath. 71:1156-1161. 